\title{
Literature Review on New Generation Cooperative Enterprise Architecture
}

\author{
Estiyan Dwipriyoko \\ Fakultas Teknik, Program Studi Informatika \\ Universitas Langlangbuana \\ Jl. Karapitan 116, Bandung \\ estiyand@unla.ac.id \\ Dr. F.Sukono, MM., M.Si. \\ FMIPA, Departemen Matematika \\ Universitas Padjadjaran \\ Bandung
}

\author{
Prof. Dr. H. Abdul Talib Bin Bon \\ Faculty of Technology Management and Business \\ Universiti Tun Hussein Onn Malaysia \\ Johor, Malaysia \\ talib@uthm.edu.my
}

\begin{abstract}
Abstrak-Cooperative is a legally incorporated business organization, that built collectively by their member, and aim to fulfill their needs. New version of Cooperative is called New Generation Cooperative (NGC) that has characters as: NGC may issue shares, individuals may hold higher levels of equity through purchase of share, and membership may be limited to shareholders.

Enterprise Architecture is the comprehensive conceptual design or blueprint of company and organization, which describes it's the structures, function, and operations. The purpose of the research is to design the Enterprise Architecture for NGC. This NGC can be started as a low cost enterprise by implementing Open Business Model. The Open Business approach places value on transparency, stakeholder inclusion, and accountability. NGC Enterprise Architecture shall purpose the Technology part of Strategic Management, which can relate New Generation Cooperative, Enterprise Architecture, and Open Business Model.
\end{abstract}

Kata kunci- new generation cooperative; enterprise architecture; open business; business model; strategic management.

\section{INTRODUCTION}

Cooperative is a business arrangement that collectively owned by its member and focus on member needs. New Generation Cooperative is a new kind of cooperative that have secured membership and give more value in their service. New Generation Cooperative has character of traditional cooperative and incorporated enterprise [1]. Currently there information about capital, investment, law and legal [1], but so little information about formal technical standards and formulation for New Generation Cooperative [2].

Enterprise Architecture is one approach for technical systems standard of enterprise [3]. Therefore the purpose of the study is to design the Enterprise Architecture for New Generation Cooperative as technical standard of enterprise that can be use as business start up template.
This New Generation Cooperative can be started as a low cost enterprise by implementing Open Business. Open Business is an enterprise approach using openness movements like open source, open tools, open standards. Open Business gives value on transparency, stakeholder inclusion, and accountability [4]. This research shall purposed the Technology Strategy that can relate New Generation Cooperative Enterprise Architecture as new category for Open Business Model.

NGC still cover financial business and agricultural product business scope. It should be applied to wider range of business segment, such as financial, production, services, human resource, sales and marketing, also strategic management. To achieve this goal is by giving producing standards to the cooperative firm. Enterprise Architecture can be one of technology approach for NGC.

There are so little information about formal standard or frameworks for New Generation Cooperatives Enterprise Architecture (NGC-EA). NGC-EA is needed to build a blueprint for cooperative firm extending to NGC. There are so little information found about NGC-EA to build Open Business Model. There are so little information about standard and formal frameworks for Open Business. Open Business is still an open discussion. Technology Strategy can be one of approach to Open Business.

\section{LITERATURE REVIEW}

\section{A. New Generation Cooperatives}

NGC was introduced in United State of America in 1990. NGC are an adaptation of traditional cooperative structures to modern capital intensive industries. This type of cooperative uses a system of delivery rights and obligations to encourage business loyalty and provide a form of vertical integration. NGC are particularly suitable to ventures involved in valueadded agricultural processing and marketing. [1] 
There are some key attributes of NGC that are consistent with all cooperatives: (1) NGC are controlled by their membership using the principle of one member, one vote, (2) Earnings are distributed to the members based on patronage, (3) The board of directors is elected by the membership. [1]

However, there are several characteristics of NGC that differentiate them from traditional cooperative : (1) NGC may issue designated shares which carry delivery rights and obligations, (2) Individuals may hold higher levels of equity through the purchase of investment shares, (3) Membership may be restricted to designated share holders. [1]

New Generation Cooperative is cooperative that has a new character. NGC characteristic that differentiate to the traditional cooperative are: (1) Value-added processing of commodities members, (2) Equity contributed by the members, (3) Product delivery obligations are based on the contribution of equity, (4) NGC has the ability to trade the equity shares and rights to delivery. [5]

Reasons to build NGC are: (1) Producers are looking for opportunities to improve margins, (2) Producers want to diversify their investment portfolios, (3) Producers want to reduce their risk, or increase their market, (4) Producers need places to market their products, (5) Producers want to increase or maintain the number of jobs in the local community. [5]

The first NGC is pioneered by the sugar beet producers of the Red River Valley, located on the North Dakota/Minnesota border in the early 1970's, and become lager in 1990's. The new generation cooperatives might be the right business structure for Producers to be used as they invest in value-added business. [5]

\section{B. Enterprise Architecture}

Enterprise Architecture is one approach for technical systems standard of enterprise [3]. Components of enterprise architecture framework [13] are : (1) Description advice: some kind of Architecture Artifacts Map or Viewpoint Library, (2) Process advice: some kind of Architecture Development Method, with supporting guidance, (3) Organization advice: including an EA Governance Model.

The view of Enterprise Architecture domains as layers (Gartner, 2003) can be presented thus: (1) Environment (the external entities and activities monitored, supported or directed by the business), (2) Business Layer (business functions offering services to each other and to external entities), (3) Data Layer (business information and other valuable stored data), (4) Information System Layer (business applications offering information services to each other and to business functions), (5) Technology Layer (generic hardware, network and platform applications offering platform services to each other and to business applications).

\section{Enterprise Architecture Planning}

Method to build New Generation Cooperative Enterprise Architecture are Enterprise Architecture Planning (EAP). Enterprise Architecture Planning is the use of enterprise business information and the implementation plan for the process of defining architecture. [8]
Figure 1 shows Enterprise Architecture Planning [8] that consists of four levels :

1. Layer 1, Planning Initiation [8], which covers in general, decisions on which methodology to use, who should be involved, what other support is required, and what tool set will be used.

2. Layer 2, Current Business and Technology Analysis [8], which consists of :

1. Business process modeling [8], the compilation of a knowledge base about the business functions and the information used in conducting and supporting the various business processes.

2. Current Systems and Technology [8], the definition of current application systems and supporting technology platforms.

3. Layer 3, Enterprise Architecture Design [8], which consists of :

1. Data Architecture [8] - Definition of the major kinds of data needed to support the business.

2. Applications Architecture [8] - Definition of the major kinds of applications needed to manage that data and support the business functions.

3. Technology Architecture [8] - Definition of the technology platforms needed to support the applications that manage the data and support the business functions.

4. Layer 4, Implementation or Migration Plans [8], which consist of definition of the sequence for implementing applications, a schedule for implementation, a cost/benefit analysis, and a clear path for migration.

\begin{tabular}{|c|c|c|}
\hline \multicolumn{3}{|c|}{ PLANNING INITIATION } \\
\hline \multicolumn{3}{|c|}{ VALUES \& PRINCIPLES } \\
\hline $\begin{array}{c}\text { CURRENT BUSINESS } \\
\text { MODELLING }\end{array}$ & $\begin{array}{c}\text { CURRENT SYSTEMS } \\
\text { \& TECHNOLOGY }\end{array}$ \\
\hline $\begin{array}{c}\text { DATA } \\
\text { ARCHITECTURE }\end{array}$ & $\begin{array}{l}\text { APPLICATION } \\
\text { ARCHITECTURE }\end{array}$ & $\begin{array}{c}\text { TECHNOLOGY } \\
\text { ARCHITECTURE }\end{array}$ \\
\hline \multicolumn{2}{|c|}{ IMPLEMENTATION \& MIGRATION PLAN } \\
\hline
\end{tabular}

Figure 1. Enterprise Architecture Planning [8]

\section{Technology Strategy}

Technology Strategy is the overall plan which consist of objectives, principles and tactics relating to use of the technologies within a particular organization. Such strategies primarily focus on the technologies themselves and people who directly manage those technologies. The strategy can be implied from the organization's behaviors towards technology decisions, and may be written down in a document [9]. Value chain is one approach for strategic management. 
Value chain [10] is a set of function of the organization that operating in a specific industry performs in order to deliver a valuable product or service for the market. This set of function can be converted to class of activity in the organization business process. Value chain will be the analysis tool for Current Business Process Analysis part of Enterprise Architecture Planning [11].

Figure 2 shows the structure of value chain. Value chain consist of two kind of activity, that is Primary Activities and Support Activities. Primary Activities or external activities are functions that deals with other entities, and they are: Inbound Logistic, Operations, Outbound Logistic, Marketing and Sales, and Service. Support Activities or internal activities are functions that deals with in the organization it self , and they are Firm Infrastructure, Human Resource Management, Technology, and Procurement. [10]

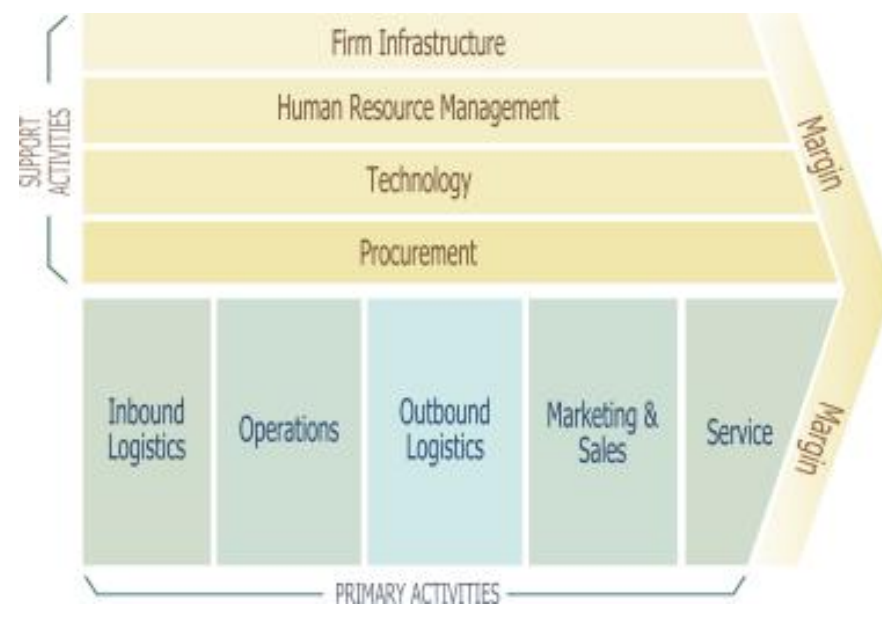

Figure 2. Value Chain [10]

\section{E. Open Business}

Open Business is an approach to enterprise that draws on ideas from openness movements like free software, open source, open content and open tools and standards. The approach places value on transparency, stakeholder inclusion, and accountability. [4] Open Business Model have six functions [4], that is:

1. Articulate the value proposition, the value created by the offering for user.

2. Identify a market segment, that is the users to whom the offering and its purpose are useful.

3. Define the structure of the value chain required by the firm to create and distribute the offering, and determine the complementary assets needed to support the firm position in this chain.

4. Specify the revenue generation mechanisms for the firm, and estimates the cost structure and profit potential of producing the offering, given the value proposition and value-chain structure chosen.
5. Describe the position of the firm within the value network, linking suppliers and customers, including identification of potential complements and competitors.

6. Formulate the competitive strategy by which the innovating firm will gain and hold an advantage over rivals.

\section{FINDINGS}

\section{A. Findings on New Generation Cooperative}

NGC still cover financial business and agricultural product business scope. It should be applied to wider range of business segment, such as financial, production, services, human resource, sales and marketing, also strategic management. To achieve this goal is by giving producing standards to the cooperative firm. Enterprise Architecture can be one of technology approach for NGC.

Figure 3 shows how New Generation Cooperative sits on organization structure based on Anthony Triangle [6]. This figure explained that Members (M1, M2, M3... Mn) is both Operational and collectively Internal Strategic part of New Generation Cooperative. The tactical part of the New Generation Cooperative will be explained by it's Value Chain structure. Value Chain is part of Strategic Management that explain function and procedures of organization. The external strategic is the rule and legal that govern the New Generation Cooperative. Malaysia use National Blue Ocean Strategy [7] for their economic development strategy, including the cooperative.

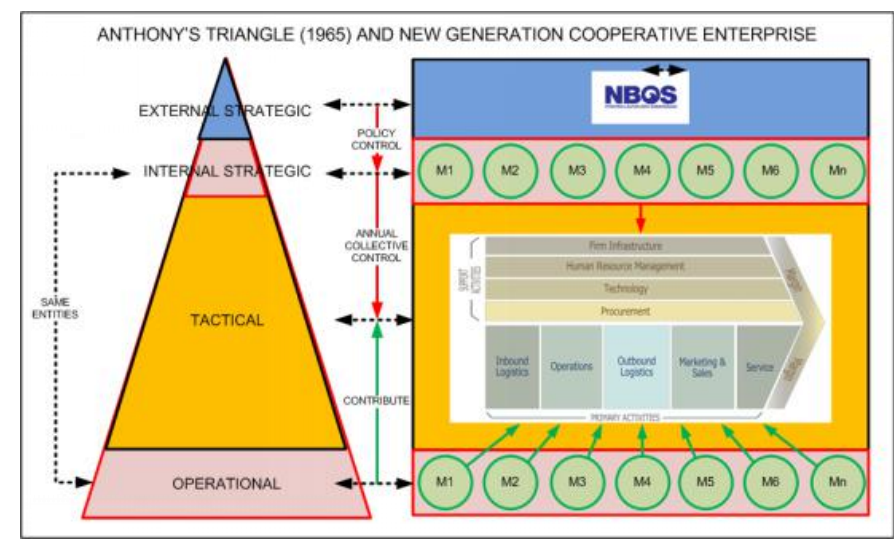

Figure 3. New Generation Cooperative and Anthony Triangle [6]

\section{B. Findings on Enterprise Architecture and EAP}

There are so little information about formal standard or frameworks for New Generation Cooperatives [1]. NGC-EA is needed to build a blueprint for cooperative firm extending to NGC.

Enterprise Architecture Planning will provides Enterprise Architecture Design as foundation for Technology Strategy of the New Generation Cooperative. 


\section{Findings on Technology Strategy}

Technology Strategy uses Strategic Management and for the implementation using Enterprise Resource Planning (ERP), implementation product from Enterprise Architecture Design.

New Generation Cooperative can be map into the Value Chain Analysis, relate to the cooperative principles. Figure 4 shows New Generation Cooperative Internal Value Chain Environment.

Strategic layer will vertically do democratic member control, one member one vote, member economic participation. Strategic layer consists of external strategic layer and Internal strategic layer. External strategic layer will give strategy, rule and integration. Government will hold external strategic role. Internal strategic layer will give annual collective decision. Board Member will hold the Internal strategic role.

Tactical layer will give concern of community and give service. Management will hold the tactical role. Member are the one that will be the target of the operational layer.

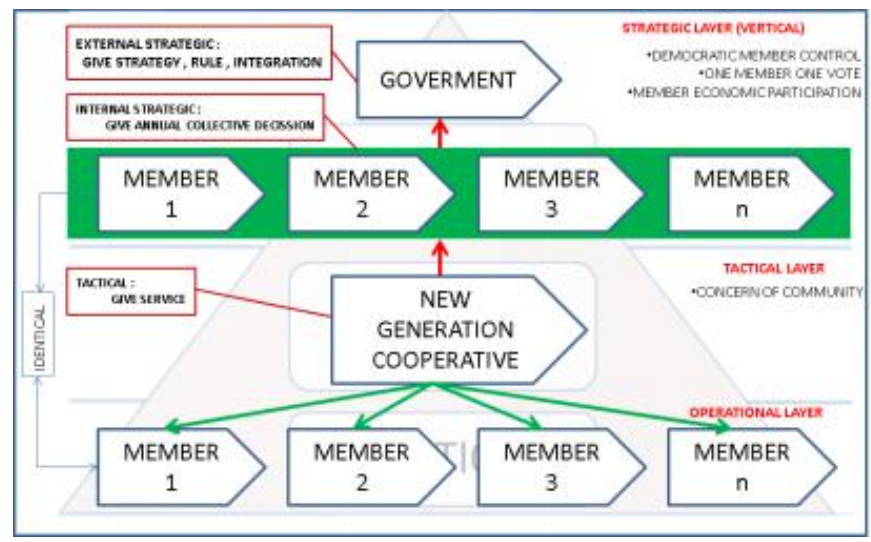

Figure 4. New Generation Cooperative Internal Value Chain Environment

Figure 5 shows New Generation Cooperative External Value Chain Environment and networked with other entities. Strategic layer will horizontally give cooperation among cooperatives, autonomy and Independence, education, training, and information.

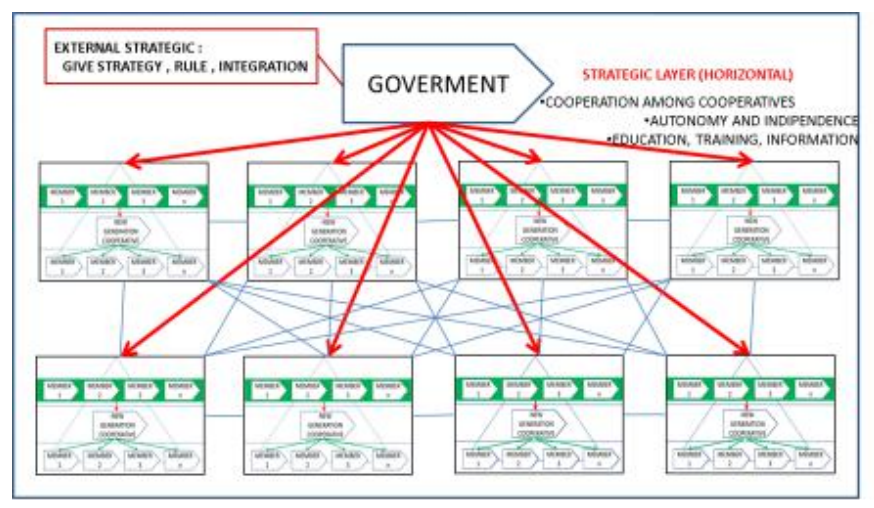

Figure 5. New Generation Cooperative External Value Chain Environment

Figure 6 shows Cooperative Principles relate to the New Generation Cooperative Value Chain Analysis.

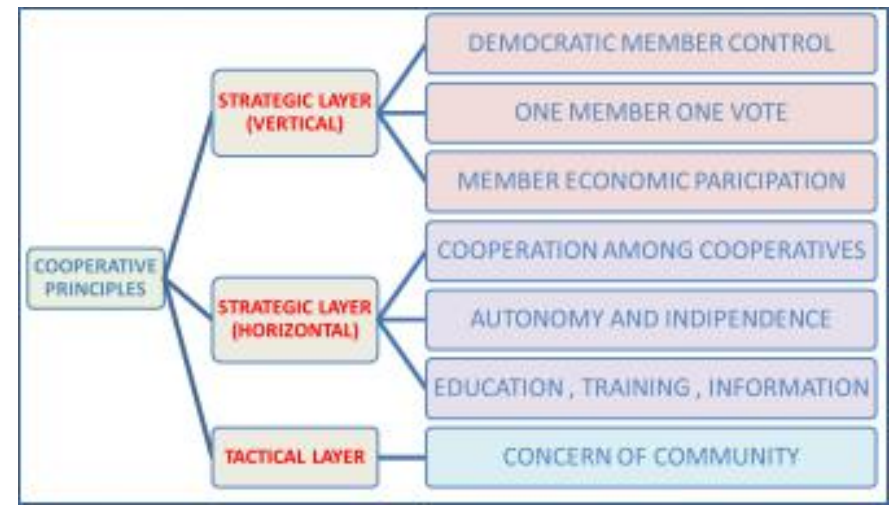

Figure 6. Cooperative Principles relate to NGC Value Chain Analysis

Value Chain Analysis can be used to map the business process classification and calculate margin of the enterprise by using cash flow in every part of the map. Every procedure segments will be considered as mathematical variables. Figure 7 shows the mathematical variable map of the value chain. [14]

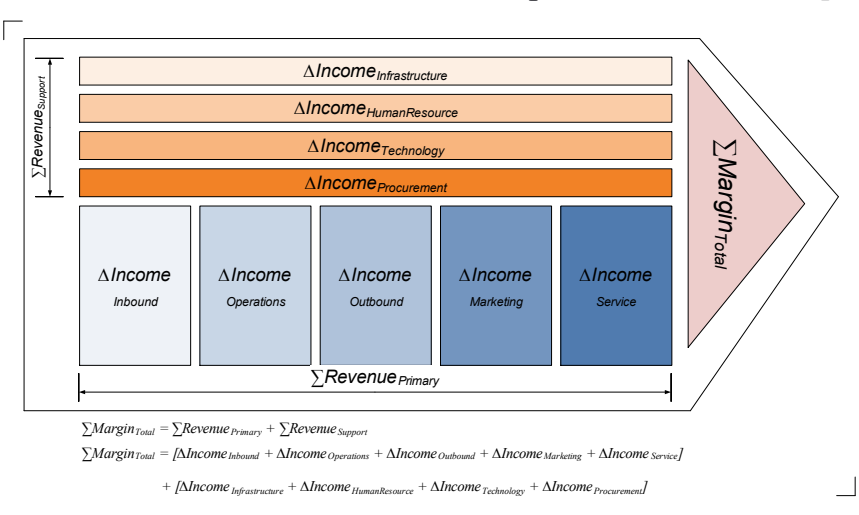

Figure 7. Value Chain Mathematical Variable Map [14]

\section{Findings on Open Business Model}

Figure 8 shows how Cooperative Principles [1] can relate to Open Business Concepts [4]. Cooperative Principles [1] are: Autonomy and Independence, Democratic Member Control, Voluntary and Open Membership, Cooperation among Cooperatives, Concern for Community, Member Economic Participation, Education,Training,Information. Open Business Concept [4] are: Institution Free, Individual Right, Open Member Details, Open Participation, Community Focus, Open Financial, Open Learning/Sharing, Open Knowledge. 


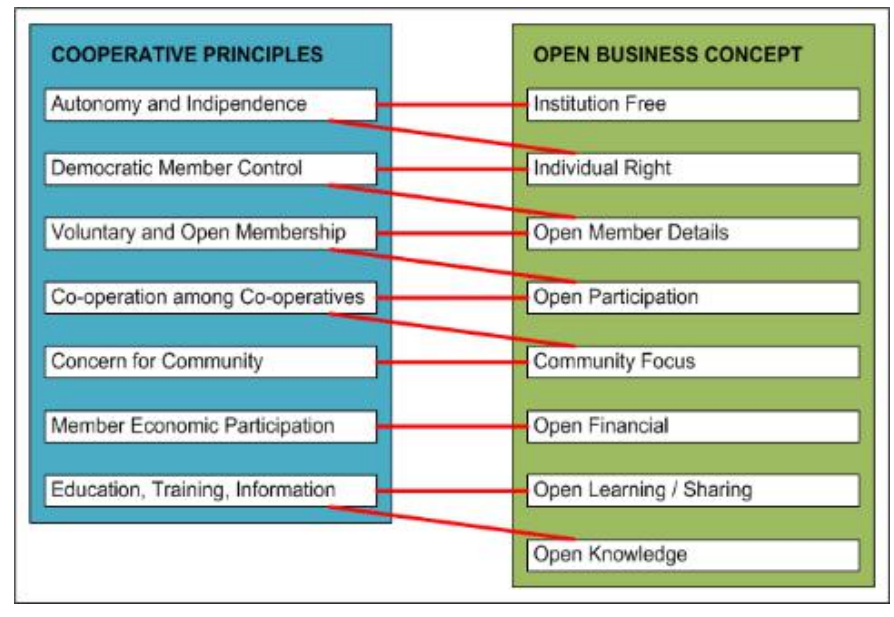

Figure 8. Cooperative Principles [1] and Open Business Concepts [4].

\section{CONCLUSION}

New Generation Cooperative is a new kind of cooperative that still cover financial business and agricultural product business scope. It should be applied to wider range of business segment, such as financial, production, services, human resource, sales and marketing, also strategic management. To achieve this goal is by giving producing standards to the cooperative firm.

Enterprise Architecture can be one of technology approach for structure and Technology part of Strategic Management of New Generation Cooperative. Enterprise Architecture Planning will provides Enterprise Architecture Design as foundation for Technology Strategy of the New Generation Cooperative.

NGC Enterprise Architecture shall purpose the Technology part of Strategic Management, which can relate New Generation Cooperative, Enterprise Architecture, and Open Business Model.

\section{REFERENCES}

[1] Coltrain,D, D.Barton, M.Boland (2000) "Differences Between New Generation Cooperatives and Traditional Cooperatives." Arthur Capper Cooperative Center, Kansas State University. May 2000

[2] Hackman, Deanne. (2001) "What is a New Generation Cooperative(NGC)?” Ag Decision Maker. Iowa State University Extension. December 2001.

[3] Zachman,J.A. (1987), A Framework for Information Systems Architecture. In: IBM Systems Journal, vol 26, no 3. IBM Publication.

[4] Chesbrough,H. (2006), Open Business Models, How to Thrive in The New Innovation Landscape, Harvard Business School Press, Boston.
[5] Schank,M. , J.Fulton (2002), "New Generation Cooperatives: What, Why, Where, and How , An Internet Guide" ID-315, Purdue University, Department of Agricultural Economics, Indiana USA

[6] Anthony,R.N. (1965), Planning and Control: a Framework for Analysis. Cambridge MA: Harvard University Press.

[7] Kim,W.C., R,Mauborgne (2004), "Blue Ocean Strategy". Harvard Business Review.

[8] Spewak, S. and S. C. Hill (1992), Enterprise Architecture Planning: Developing a Blueprint for Data, Applications, and Technology. Boston, QED Pub. Group.

[9] Floyd, S.W. \& Wolf, C. (2010), 'Technology Strategy' In: Narayanan, V.K. \& O'Connor, G.C. (eds.) Encyclopedia of technology and innovation management. West Sussex: Wiley pp. 125-128. ISBN 14051-6049-7

[10] Porter,M.E. (1985), Competitive Advantage: Creating and Sustaining Superior Performance. New York.: Simon and Schuster.

[11] Walters,D., M.Rainbird, (2007), Cooperative innovation: a value chain approach. Journal of Enterprise Information Management, 20(5), 595-607.

[12] Spewak,S., M.Tieman, (2006), "Updating The Enterprise Architecture Planning Model", Journal of Enterprise Architecture, May 2006

[13] Gartner (2003), IT Glossary - Enterprise Architecture (EA) http://www.gartner.com Retrieved on 2013-07-29.

[14] Dwipriyoko, E., Bon, ATB., Sukono, F., (2017), New Generation Cooperative Financial Mathematical Model Preliminary Concept, Journal of Engineering and Applied Sciences, Vol.12, Issue 18. 